\title{
Prevalence of measles antibody in children of different ages in Shiraz, Islamic Republic of Iran
}

A. Karimi, ${ }^{1}$ A. Arjomandi, ${ }^{1}$ A. Alborzi, ${ }^{1}$ M. Rasouli, ${ }^{1}$ M. R. Kadivar,${ }^{1}$ B. Obood ${ }^{1}$ and B. Pourabbas $^{1}$

$$
\begin{aligned}
& \text { معدل انتشار أضداد الحصبة لدى الأطفال من مختلف الأعمار في شيراز، جمهورية إيران الإسلامية }
\end{aligned}
$$

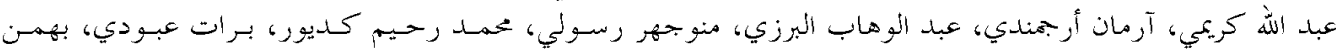

$$
\begin{aligned}
& \text { بورعباس }
\end{aligned}
$$

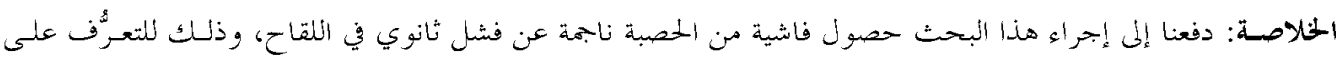

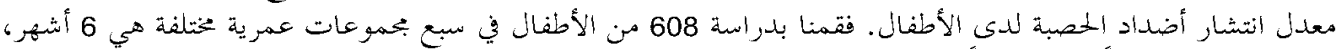

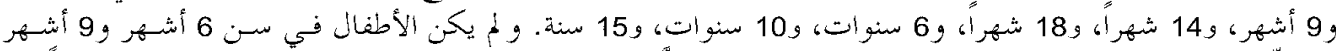

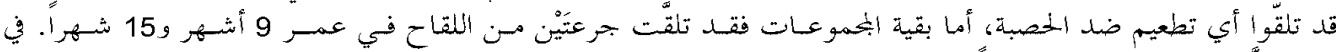

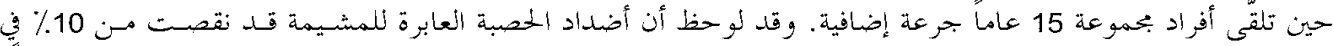

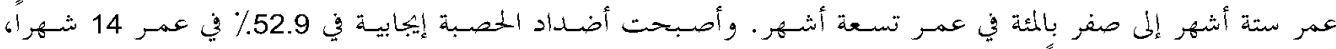

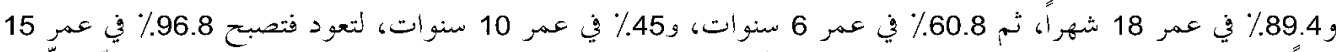

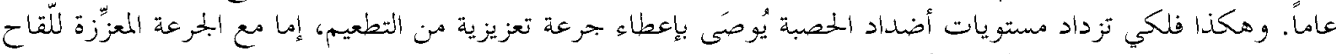

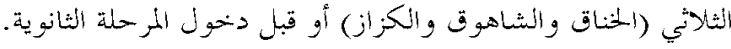

ABSTRACT An outbreak of measles due to secondary vaccine failure prompted this investigation into the prevalence of measles antibody in children. We studied 608 children in 7 different age groups: 6, 9, 14 and 18 months and 6,10 and 15 years. Children in the 2 youngest groups received no vaccination; the rest were vaccinated at 9 months and 15 months. The 15-year-old age group received an additional vaccination. Transplacental measles antibody (Ab) decreased from $10.0 \%$ at 6 months to $0 \%$ at 9 months. Measles $\mathrm{Ab}$ was positive in $52.9 \%$ ( 14 months), $89.4 \%$ (18 months), $60.8 \% 96$ years), $45.0 \%$ (10 years) and $96.8 \%$ ( 15 years). To increase Ab levels, a booster vaccination is recommended, administered either with the second DPT booster or at pre-high school age.

Prévalence des anticorps antirougeoleux chez des enfants de différents âges à Chiraz (République islamique d'Iran)

RÉSUMÉ Une flambée de rougeole due à l'échec de la vaccination secondaire a conduit à effectuer une étude de la prévalence des anticorps antirougeoleux chez les enfants. Nous avons étudié 608 enfants dans sept groupes d'âge différents : 6, 9, 14 et 18 mois et 6, 10 et 15 ans. Les enfants des deux groupes d'âge les plus jeunes n'avaient pas été vaccinés ; le reste des enfants avaient été vaccinés à l'âge de 9 et 15 mois. Le groupe des enfants de 15 ans avait eu une vaccination supplémentaire. Les anticorps transplacentaires diminuaient, passant de 10,0 \% à l'âge de 6 mois à $0 \%$ à l'âge de 9 mois. Dans les groupes d'âge étudiés, la proportion des enfants présentant des anticorps antirougeoleux par âge était de 52,9\% (14 mois), 89,4\% (18 mois), 60,8 \% (6 ans), 45,0 \% (10 ans) et 96,8 \% (15 ans). Afin d'augmenter les taux d'anticorps, une vaccination de rappel est recommandée, à administrer soit avec le deuxième rappel DTC soit à l'âge correspondant au cycle d'enseignement pré-secondaire.

${ }^{1}$ Clinical Microbiology Research Centre, Shiraz University of Medical Sciences, Shiraz, Islamic Republic of Iran.

Received : 10/10/02; accepted: 21/09/03

بلملة الصحية لشرق المثتوسط، منظمة الصحة العلامية، البحلد العاشر، العددان ع-0، ع • •؟ 


\section{Introduction}

Prevention of measles using vaccination is still the most important task in developing countries. The disease is a substantial cause of mortality and morbidity in children. It is highly contagious but preventable [1]. Mortality has declined dramatically since the introduction of a live attenuated vaccine. Despite an $85 \%$ decrease in mortality, however, outbreaks of measles have been reported due to secondary vaccine failure in older age groups (10-24 years), e.g. in a study of measles epidemiology by the Iranian Minister of Health and Medical Education in 1998 [2]. This has led some countries, including the United States of America, to introduce an additional dose of vaccine in school-age children. In the Islamic Republic of Iran, the decline in measles incidence due to the vaccination programme has been noticed in children; cases in older age groups are, however, still emerging. This might be due to immigration from neighbouring countries such as Afghanistan and Pakistan, which have a vaccine coverage of less than $80 \%$ (unpublished report, Ministry of Health and Medical Education, 1988).

Our study was conducted to disclose the prevalence of measles antibodies in different age groups and to evaluate the necessity of administering additional doses of vaccine. The study was prompted by an outbreak of measles in our country in 1997.

\section{Methods}

Over the period 2001-02 we enrolled 608 children into the study in 7 different age groups. Details of the groups and their vaccination history are given in Table 1 . The children were selected by random cluster sampling of children referred to the Motahhari out-patient clinic or from primary schools in Shiraz. The epidemiological data including sex, age, socioeconomic status, number of family members and vaccination history were obtained. For antibody (Ab) testing, $5 \mathrm{~mL}$ of blood was drawn and serum was separated and frozen at $-20^{\circ} \mathrm{C}$. The sera were examined using an enzymelinked immunosorbent assay IgG kit (Morbillio, Radim SpA, Pomezia, Italy). Samples with optical density (OD) lower than the cut-off control (OD $<0.200)$ were considered non-reactive for measles IgG antibodies. Samples with OD higher than the cut-off control (OD > 0.700) were considered reactive for measles IgG antibodies. Samples with absorbance values $\pm 10 \%$ of the cut-off (OD 0.200 to 0.700 ) control were considered questionable and were retested for confirmation.

\section{Results}

We enrolled 608 children, 52\% male and $48 \%$ female, in the study. Table 2 shows

\section{Table1 Vaccination history for children in} seven different age groups

\begin{tabular}{|c|c|c|c|}
\hline Group & No. & Age & Vaccination history \\
\hline 1 & 70 & $6 \mathrm{~m}$ & No vaccination \\
\hline 2 & 62 & $9 \mathrm{~m}$ & No vaccination \\
\hline 3 & 70 & $14 \mathrm{~m}$ & Vaccinated at $9 \mathrm{~m}$ \\
\hline 4 & 66 & $18 \mathrm{~m}$ & $\begin{array}{c}\text { Vaccinated at } 9 \mathrm{~m} \\
\text { and } 15 \mathrm{~m}\end{array}$ \\
\hline 5 & 97 & $6 y$ & $\begin{array}{l}\text { Vaccinated at } 9 \mathrm{~m} \\
\text { and } 15 \mathrm{~m}\end{array}$ \\
\hline 6 & 149 & $10 y$ & $\begin{array}{l}\text { Vaccinated at } 9 \mathrm{~m} \\
\text { and } 15 \mathrm{~m}\end{array}$ \\
\hline 7 & 94 & $15 y$ & $\begin{array}{l}\text { Vaccinated at } 9 \mathrm{~m} \text {, } \\
15 \text { months and } 9 \mathrm{~m} \\
\text { prior to the study }\end{array}$ \\
\hline
\end{tabular}

$m=$ months. $\quad y=$ years.

لبحلة الصحية لشرق المثتوسط، منظمة الصحة العلمية، البحلد العاشر، العدذان ع-0، ع • • 


\begin{tabular}{|c|c|c|c|c|c|c|c|}
\hline \multirow{3}{*}{$\begin{array}{l}\text { Age } \\
6 \mathrm{~m}\end{array}$} & \multirow{3}{*}{$\begin{array}{c}\begin{array}{c}\text { Total } \\
\text { No. }\end{array} \\
70\end{array}$} & \multicolumn{2}{|c|}{ Ab positive } & \multicolumn{2}{|c|}{ Ab negative } & \multirow{2}{*}{\multicolumn{2}{|c|}{$P$-values between different age groups }} \\
\hline & & No. & $\%$ & No. & $\%$ & & \\
\hline & & 7 & 10.0 & 63 & 90.0 & & \\
\hline $9 \mathrm{~m}$ & 62 & 0 & - & 62 & 100.0 & $6 \mathrm{~m}$ and $9 \mathrm{~m}$ & 0.014 \\
\hline $14 \mathrm{~m}$ & 70 & 37 & 52.9 & 33 & 47.1 & $9 \mathrm{~m}$ and $14 \mathrm{~m}$ & 0.00001 \\
\hline $18 \mathrm{~m}$ & 66 & 59 & 89.4 & 7 & 10.6 & $18 \mathrm{~m}$ and $6 \mathrm{y}$ & 0.00006 \\
\hline $6 y$ & 97 & 59 & 60.8 & 38 & 39.2 & $6 y$ and $10 y$ & 0.016 \\
\hline $10 y$ & 149 & 67 & 45.0 & 82 & 55.0 & $10 y$ and $15 y$ & 0.00001 \\
\hline $15 y$ & 94 & 91 & 96.8 & 3 & 3.2 & All age groups & 0.00001 \\
\hline Total & 608 & 320 & 50.7 & 288 & 49.3 & & \\
\hline
\end{tabular}

$m=$ months. $\quad y=$ years.

the frequency of measles Ab prevalence in each age group. Antibody prevalence was higher in girls, although the result was not statistically significant. The Ab prevalence was significantly different in all consecutive age groups $(P=0.00001)$. The $P$-values for the different age groups are shown in Table 2. Number of family members, socioeconomic status and literacy of parents were not significant (data not shown).

Transplacental IgG from mothers declined from $10.0 \%$ at 6 months to $0 \%$ at 9 months of age in non-vaccinated children. Although this is unusual and we do not have good explanation for it, it is possible the titre of measles $\mathrm{Ab}$ in our pregnant women was very low due to low contact with wild measles viruses. However, in infants more than 9 months old, the prevalence of $\mathrm{Ab}$ increased owing to vaccination at 9 months and 15 months of age, and declined over time thereafter.

Primary vaccine failure is defined as a no detectable antibody after vaccination. It can be caused by interaction of maternal antibody to the vaccine by immunological response, technical problems, and so on. Primary vaccine failure in our study was
$47.1 \%$ in the 14 -month-old group, reducing to about $10.6 \%$ in the 18 -month-old group due to the second dose of vaccine given at 15 months. Primary vaccine failure was $55 \%$ at age 10 , reducing to $3.2 \%$ at 15 due to the third vaccine administration.

\section{Discussion}

Measles is a highly contagious, preventable disease. The incidence has shown a remarkable decline in our county over recent years due to routine administration of live, attenuated vaccine at the ages of 9 months and 15 months, but several reports of disease outbreak in older age groups have been documented $[2,3]$. The presence of measles $\mathrm{Ab}$ indicates previous infection, active immunization or, at ages below 9 months, maternal $\mathrm{Ab}$ transmission, all of which offer immunity.

Our study was conducted to determine the pattern of Ab prevalence in different age groups of children. In this study, transplacental $\mathrm{Ab}$ was detected in only $10.0 \%$ of 6 month-old infants, declining to $0 \%$ at 9 months. This finding is in accord with pre-

بلملة الصحية لشرق المثتوسط، منظمة الصححة العلمية، المجلد العاشر، العددان ع-0، ع • •؟ 
vious studies from Iran [4,5]. The decline of maternal antibody in infants in different geographic areas is dependent on socioeconomic states, catabolism of antibody, amount of antibody transmission to fetus, level of maternal antibody, and so on. In some studies it was shown to be between $0 \%$ and $10 \%$ at about 11 months of age $[2,4]$. Therefore, a high percentage of children at 6 months of age are also susceptible in an outbreak of the disease. It has been documented that the Schwarz type vaccine that is used in the Islamic Republic of Iran is not so effective for 6-month-old infants [6,7]. The absence of Abs during outbreaks was $47.1 \%$ at 14 months, 1 month before the second vaccination and $10.6 \% 3$ months afterwards. This finding was in accordance with previous studies [8-10]. High primary vaccine failure at 9 months of age might be related to trans-placental $\mathrm{Ab}$ from mothers [8].

Other possible factors responsible for this high primary vaccine failure include nutritional status of children [11], acute disease during vaccination [12-14] and concomitant administration of gamma globulin [15], race, environmental factors $[16,17]$, sex [18] and immunity status of those being vaccinated $[19,20]$. In our study, sex and literacy were not statistically important factors in primary vaccine fail- ure. Measles $\mathrm{Ab}$ was positive in $89.4 \%$ of the 18 -month-old children and $60.8 \%$ at 6 years of age, which was statistically significant $(P<0.001)$. In the 10 -year-old group, only $45.0 \%$ of the children were positive for measles $\mathrm{Ab}(P=0.016)$. This Abwaning phenomenon is reported to be about $2 \%-20 \%$ in several studies [21-24]. The presence of Ab may be due to the vaccine effect or to previous infection with wild virus. The waning of $\mathrm{Ab}$ titre is greater in subjects who produce lower initial Ab titres. Accordingly, a single vaccination produces more significant $\mathrm{Ab}$ waning [25]. An important observation was the significant rise in the $\mathrm{Ab}$ titre of the 15-year-old age group following the administration of an additional booster dose of the vaccine, compared to the 10-year-old age group ( $P$ $<0.00001$ ) (Table 2). The necessity for an additional immunization is also emphasized in a report from Singapore [26] and in other countries $[27,28]$. Therefore, an additional dose of measles vaccine is recommended for Iranian children around high-school age.

\section{Acknowledgement}

The authors wish to thank Dr A. Japoni for his help in preparing the manuscript.

\section{References}

1. Issacs D, Menser M. Modern vaccines, measles, mumps, rubella, and varicella. Lancet, 1990, 335:1384-7.

2. Study of measles epidemiology in Iran during 1991 to 1998. Annual report of the Minister of Health and Medical Education. Tehran, Ministry of Health and Medical Education, 1998.

3. Health picture. Annual report of the Minister of Health and Medical Education.
Tehran, Ministry of Health and Medical Education, 2002.

4. Mirchamsy $\mathrm{H}$ et al. Age of measles immunization in tropics. Developments in biological standardization, 1978, 41: 191-4.

5. Mokhtariazad T. Evaluation of measles vaccination in 6-month infants [thesis]. Tehran, Tehran University of Medical Sciences, 1982.

البحلة الصحية لشرق المثتوسط، منظمة الصحة العالمية، البملد العاشر، العلدان ع-0، ع • • 
6. Markowitz LE et al. Immunization of sixmonth-old infants to different doses of Edmonston-Zagreb and Schwarz measles vaccine New England journal of medicine, 1990, 322:580-7.

7. Tidjani $O$ et al. Serological effects of Edmonston-Zagreb, Schwarz and AlK$\mathrm{C}$ measles vaccine strains given at ages 4-5 or 8-10 months. Lancet, 1989, 11: 1357-60.

8. Shelton JD et al. Measles vaccine efficacy: Influence of age at vaccination vs duration of time since vaccination. Pediatrics, 1978, 62:961-4.

9. Mirchamsy $\mathrm{H}$ et al. Comparative field trial of five measles vaccines produced in human diploid cell, MRC-S. Journal of biological standardization, 1977, 5:118.

10. Mirchamsy $\mathrm{H}$ et al. Mass immunization of children in Iran with live attenuated Sugiyama virus adapted to calf kidney cell cultures. Japanese journal of experimental medicine, 1971, 41:39-40.

11. Wesley A, Coovadia HM, Henderson L. Immunological recovery after measles. Clinical and experimental immunology, 1978, 32:540-4.

12. Krober MS, Stracener CE, Bass JW. Decreased measles antibody response after measles-mumps-rubella vaccine in infants with colds. Journal of the American Medical Association, 1991, 265(16): 2095-6.

13. Halsey NA et al. Response to measles vaccine in Haitian infants 6 to12 months old. New England journal of medicine, 1985, 313(9):544-9.

14. Ndikuyeze A et al. Immunogenicity and safety of measles vaccines in ill African children. International journal of epidemiology, 1988, 17(2):448-55.

15. Krugman S. Present studies of measles and rubella immunization in the United
States: a medical program report. Pediatrics, 1971, 78:1-16.

16. Black FL et al. Geographic variation in infant loss of maternal measles antibody and in prevalence of rubella antibody. American journal of epidemiology, 1986, 124(3):442-52.

17. Neiburg P, Dibley MJ. Risk factors for fatal measles infection. International journal of epidemiology, 1980, 15(3): 309-11.

18. Bromberg $\mathrm{K}$ et al. Maternal immunity to measles and infant immunity at less than twelve months of age relative to maternal place of birth. Journal of pediatracs, 1994, 125(4):579-81.

19. Dai $B$ et al. Duration of immunity following immunization of live measles vaccine. Bulletin of the World Health Organization, 1991, 69(4):415-23.

20. Markowitz LE et al. Persistence of measles antibody after revaccination. Journal of infectious diseases, 1992, 166(1):205-8.

21. Climie A, Andre FE. Field trial of heatstable measles vaccine in Papua New Guinea. Journal of tropical medicine and hygiene, 1984, 87(6):249-55.

22. Zhuji Measles Vaccine Study Group. Epidemiologic examination of immunity period of measles vaccine. Chinese medical journal, 1987, 67:19-22 [in Chinese].

23. Xiang JZ, Chen AH. Measles vaccine in the People's of Republic of China. Reviews of infectious diseases, 1983, 5(3): 506-10.

24. Gdalevich $M$ et al. Measles epidemic in Israel-successful containment in the military. Preventive medicine, 2000, 31(6):469-51.

25. Smith FR et al. Reported measles in persons immunologically primed by prior

بلملة الصحية لشرة المتو سط، منظمة الصحة العالمية، البحلد العاشر، العلددان ع-0، ع • • 
vaccination. Journal of pediatrics, 1982 , 101(3):391-3.

26. Goh D et al. Resurgence of measles in Singapore: profile of hospital cases. Journal of paediatrics and child health, 1999, 35(5):493-6.

27. Christenson B, Bottiger M. Measles antibody comparison of long-term vaccina- tion titer, early vaccination titers and naturally acquired immunity. Vaccine, 1994, 12(2):129-33.

28. Olsha $M$ et al. Measles immunity in Israeli young adults. Israel journal of medical sciences, 1994, 30:596-9.

\section{Measles mortality reduction}

Measles remains a leading cause of death among young children, despite the availability of a safe and effective vaccine for the past 40 years. More than half a million people, the majority of them children, died from measles in 2003; in the Eastern Mediterranean Region (EMR) there were an estimated 69000 deaths from measles. WHO and UMICEF have developed a joint Strategic Plan for Measles Mortality Reduction and Regional Elimination 2001-2005. The overriding goal of this plan is to reduce the number of global measles deaths (from the 1999 level) by $50 \%$ by the end of 2005. The priority countries in EMR are Afghanistan, Djibouti, Pakistan, Somalia and Sudan. The four-pronged strategy for sustainable measles mortality reduction is based on: providing strong routine immunization; providing a "second opportunity" for measles immunization to all children; surveillance; improvement in the clinical management of measles cases. Thus, from 1999 to 2003, more than 350 million children globally received measles vaccine through supplementary immunization activities. Moreover, improvements were made in routine immunization over this period. These accelerated activities have resulted in a significant reduction in estimated global measles deaths. Overall, global measles mortality decreased by $39 \%$ between 1999 and 2003. Given the progress made to date, it is expected that the 2005 global measles mortality reduction goal will be achieved.

Source: WHO Fact sheet No. 286 Available at: http://www.who.int/mediacentre/factsheets/fs286/en/

البلة الصحية لشرق المتو سط، منظمة الصحة العالمية، البملد العاشر، العددان ع-0، ع • • 